
\title{
28 Research Suare \\ Experimental Evaluation of an Antimicrobial Protein from Bacillus Amyloliquefaciens MBL27 for Wound Healing Potential in Rats
}

Vijayalakshmi K ( $\nabla$ vijayalk3@srmist.edu.in )

SRM Institute of Science and Technology https://orcid.org/0000-0002-5856-4605

G. Suseela Rajakumar

Central Leather Research Institute: Central Leather Research Institute CSIR

\section{Research Article}

Keywords: animal models, antimicrobial protein, Bacillus amyloliquefaciens, chitosan, collagen, wound healing.

Posted Date: October 29th, 2021

DOl: https://doi.org/10.21203/rs.3.rs-973755/v1

License: (c) (i) This work is licensed under a Creative Commons Attribution 4.0 International License.

Read Full License 


\section{Abstract}

Objective: This study was aimed at assessing the ability of the antimicrobial protein (AMP) produced by Bacillus amyloliquefaciens MBL27 as a potent wound healant.

Methods: Rat models were used to study the efficacy of AMP and AMP incorporated chitosan sheet along with control groups.

Results: AMP and AMP incorporated chitosan sheet significantly improved wound contraction when compared to controls. Rate of wound contraction (97.23\%), decreased period of epithelialization (14 days) and the levels of biochemical markers such as hydroxyproline (collagen), hexosamine, uronic acid and total protein in the granulation tissue on various days of wound healing revealed the wound healing efficacy of the AMP. The histological examinations also correlated well with the biochemical findings, confirming the wound healing efficacy of the AMP.

Conclusion: The results indicate the beneficial effects of AMP from B.amyloliquefaciens MBL27 and its potential to be developed into new therapeutic agent for dermal wound healing.

\section{Introduction}

Wound healing is tissue remodelling process in which the injured tissue is removed and substituted with normal tissue. This complex process is regulated by a pattern of events, in which a large number of resident and infiltrating cells are involved including keratinocytes, fibroblasts, neutrophils, macrophages, lymphocytes and mast cells [1, 2]. Wound care and maintenance involves numerous factors viz., dressing and administration of painkillers, anti-inflammatory agents, healing promoting drugs etc. It also involves phases such as coagulation, inflammation, granulation, fibroplasias, collagenation, wound contraction and epithelialization [3].

The process of wound healing is reported to be accelerated by exogenous application of biological macromolecules such as collagen or chitosan or, the bioactive peptide such as growth factors on the wound surface. A biomaterial should be non-irritant, non-toxic, sterilizable, non-antigenic, noncarcinogenic and should not cause any inflammatory reaction to the neighbouring tissues. Chitin and chitosan are well known for wound healing activity $[4,5]$. Chitosan simulates the migration of polymorphonuclear (PMN) and mononuclear cells and accelerates the reepithelialization and regeneration of normal skin and healing occurs without excessive granulation tissue and scar formation $[6,7]$.

Antimicrobial peptides have been isolated from microorganisms, plants, animals, and human. Various bioactive peptides or proteins have been found in amphibian skins [8]. These peptides exhibit microbekilling, defense against either predators or parasites, wound healing, and oxidant scavenging activities [9 11]. The skin of R.dybowskii has been used extensively in traditional Chinese medicine to heal open and burn wounds and the antimicrobial components may contribute to its efficacy in wound healing [12]. 
Ranalexin, an antimicrobial peptide (AMP), in combination with lysostaphin, an antistaphylococcal endopeptidase, synergistically inhibits the growth of MRSA and it could be used in wound dressings for the prevention and treatment of topical S.aureus infections [13].

It has been reported that cells and/or the metabolic by-products of Lactobacilli have antagonistic effects against pathogens in vitro and also in vivo during trials with urinary and genital infections in humans and mice [5].

Selection of proper healant and the method of application also determine the rate of healing. In recent years, the effect of dressing on dermal repair has received much attention. Hence the present study was focused to evaluate the AMP isolated from B.amyloliquefaciens MBL27 for its wound healing potential. The objective in wound management is to heal the wound in the shortest time possible, minimal pain, discomfort and scaring.

\section{Material And Methods}

\section{Animals}

Female albino wistar rats weighing $~ 120-150 \mathrm{~g}$ were used for this study. The rats were purchased from King Institute of Preventive Medicine, Chennai. They were maintained in individual metabolic cages throughout the experiment, in hygienic conditions and they were fed with commercial balanced diet and water ad libitum. Institutional Animal Ethics Committee (IAEC) constituted by Central Leather Research Institute, Chennai, INDIA approved all the protocols of animal experiments of this study (IAEC Reg.No. 06/002/08).

\section{Preparation of AMP}

$1000 \mathrm{ml}$ of the production medium was inoculated with $1.0 \%(\mathrm{v} / \mathrm{v})$ inoculum of B.amyloliquefaciens MBL27 containing $2.2 \times 10^{6} \mathrm{cells} / \mathrm{ml}$ and incubated at $30^{\circ} \mathrm{C}$ for $36 \mathrm{~h}$ at $200 \mathrm{rpm}$ for AMP production [14]. Antimicrobial protein (AMP) was recovered from culture supernatant by precipitation using $40 \%$ ammonium sulphate followed by centrifugation at 10,000 rpm using a refrigerated centrifuge (SIGMA, Model $3 \mathrm{~K} 30$ ) at $4^{\circ} \mathrm{C}$ for $15 \mathrm{~min}$. The crude antimicrobial protein was dialysed, filter sterilized using sterile $0.22 \mu \mathrm{m}$ syringe filter (Millipore, Bedford, MA, USA) and lyophilized. This preparation was used for the wound healing studies.

\section{Preparation of chitosan sheets}

Chitosan ( $1 \% \mathrm{w} / \mathrm{v})$ was dissolved in $0.05 \mathrm{M}$ acetic acid by stirring in a magnetic stirrer for 2-3 $\mathrm{h}$. It was then filtered in a sintered glass filter to remove the extraneous matter and poured as a uniform layer onto a polypropylene plate carefully without any air bubbles. It was allowed to dry in a drying oven at $37^{\circ} \mathrm{C}$ for $24 \mathrm{~h}$ [15]. After drying, the sheets were peeled from the plate and washed with distilled water to remove 
the acetic acid and allowed to dry. It was then stored in a dessicator at room temperature and relative humidity of $60-65 \%$ for property measurements and wound healing studies.

\section{Thickness of the sheet}

The thickness of the sheet was measured using a micrometer (Digimatic Micrometer, Mitutoyo, Tokyo, Japan) at five locations and the mean thickness calculated.

\section{Moisture content of the sheet}

Moisture content (MC\%) of the membrane was determined by drying $3 \mathrm{~cm}^{2}$ pieces of samples in an oven at $105^{\circ} \mathrm{C}$ for $24 \mathrm{~h}$.

\section{Water uptake study (or) swelling index}

Water absorption was calculated by taking the chitosan sheet of $3 \times 3 \mathrm{~cm}^{2}$ dimension. The dry weight was taken before soaking the material in $0.1 \mathrm{M}$ phosphate buffer saline (PBS) pH 7.4. The sheet was removed from the buffer at regular time intervals and blotted in a filter paper and weighed. The sample mass change resulting from water uptake was calculated according to the following formula:

$$
\% D m=\left(m_{t}-m_{o} / m_{o}\right) \times 100
$$

where $m_{0}$ and $m_{t}$ are the masses of dry and wet samples, respectively.

\section{Water Vapour Transmission Rate (WVTR)}

The moisture permeability of the bilayer wound dressing was measured by its water-vapor transmission rate across the material following the modified ASTM standard method E 96 at $80 \%$ relative humidity calculated from the formula:

$$
\operatorname{WVTR}=(\mathrm{m} / \mathrm{Dt}) \cdot 24 / \mathrm{A}\left(\mathrm{g} / \mathrm{m}^{2} / \mathrm{day}^{1}\right)
$$

where $m$ is the mass loss over time interval $(\mathrm{g}), \mathrm{Dt}$ is the time interval $(\mathrm{h})$, and $\mathrm{A}$ is the effective transfer area $\left(10^{-2} \mathrm{~m}^{2}\right)$.

\section{Wound creation and treatment}

Female albino rats weighing approximately $120-150 \mathrm{~g}$ were used for the study. Hairs on the back of the rats were shaved and open excision wounds of standard size $(2 \times 2 \mathrm{~cm})$ were made using a template. Six groups were studied, one being positive control, one being negative control and the other four groups experimental. The animals were grouped and treated as follows and observed for healing.

Group I - Wounds were topically applied with sterile water, once a day (Negative control). 
Group II - Wounds were topically applied with cipladine ointment (Povidone-iodine), once a day (Positive control).

Group III - Wounds were topically applied with aqueous solution of the AMP at a concentration of 1 $\mathrm{mg} / \mathrm{cm}^{2}$ wound area, once a day.

Group IV - Wounds were topically applied with aqueous solution of the AMP at a concentration of 2 $\mathrm{mg} / \mathrm{cm}^{2}$ wound area, once a day.

Group V - Wounds were treated with chitosan sheets, prepared for this study using $1 \%(\mathrm{w} / \mathrm{v})$ chitosan in $0.05 \mathrm{M}$ acetic acid, once a day.

Group VI - Wounds were treated with AMP incorporated chitosan sheet (AMP at lower concentration 1 $\mathrm{mg} / \mathrm{cm}^{2}$ ), once a day.

\title{
Wound assessment by planimetry
}

The size of the wounds of control and experimental animals was measured using transparent graph sheet and the rate of healing was calculated and expressed as percentage contraction [16].

The formula used to calculate the percentage of wound contraction was

\section{Wound area day 0 - Wound area day ' $\mathrm{n}$ '}

\author{
Wound contraction $(\%)=\longrightarrow \times 100$ \\ Wound area day ' $\mathrm{n}$ '
}

\section{Antimicrobial activity}

The antimicrobial efficacy of AMP incorporated dressing was tested by using $1 \mathrm{~cm}^{2}$ of the sheet. It was placed on the centre of the agar plates inoculated with a mixed culture constituting of S.aureus, E.coli and P.aeruginosa in accordance with the Kirby-Bauer disk diffusion test [17]. AMP activity was measured as zone of inhibition in mm using zone measuring scale (HIMEDIA).

\section{Biochemical parameters}

Protein in granulation tissues was extracted in 5\% TCA (Trichloro acetic acid) by Porat et al. method [18] and the estimation was done by Lowry et al [19] method. For estimation of collagen and hexosamine, the tissue samples collected at various times and after wound healing were defatted in chloroform: methanol (2:1) and dried in acetone, before use. Weighed tissues was first hydrolyzed in $6 \mathrm{~N} \mathrm{HCl}$ for $18 \mathrm{~h}$ 
at $110^{\circ} \mathrm{C}$, evaporated to dryness, and then made up with a known volume of water. Collagen and hexosamine were estimated by Woessner [20] and Elson \& Morgan method [21] respectively. For uronic acid estimation digestion of the wound tissue was done with crude papain in $0.5 \mathrm{M}$ acetate buffer, $\mathrm{pH} 5.5$, containing $0.005 \mathrm{M}$ cysteine and $0.005 \mathrm{M}$ disodium salt of EDTA at $65^{\circ} \mathrm{C}$ for $24 \mathrm{~h}$ and the estimation was done by Schiller et al. method [22]. In addition, the microbial count in terms of CFU/ml at the wound site was also determined.

\section{Histopathology}

Histological sectioning of the samples was done by separately fixing the samples in $10 \%$ formalin, dehydrated through graded alcohol series, cleared in xylene and embedded in paraffin wax. Thin sections were cut and hematoxylin and eosin staining was done. The sections were examined under a light microscope and photomicrographs were taken. Massons's trichrome staining was also done to determine the amount of collagen deposition.

\section{Statistical analysis}

Data are expressed as mean \pm S.E. Analysis of variance (ANOVA) followed by the student-unpaired ' $t$ ' test was used to determine the significant differences among the groups. ' $p$ ' value less than 0.05 were significant. All statistical analyses were performed using SPSS statistical software version 11.0.

\section{Results}

Table 1 depicts the results of all the physical properties of the chitosan sheet. All used chitosan sheets were transparent and slightly yellowish in colour. The SEM images show the uniform thickness of the sheet and it also shows the uniform binding of the drug throughout the sheet. The thickness of the chitosan sheet was $40-45 \mu \mathrm{m}$.

\section{Moisture content (\%) and Swelling index}

The moisture content of the chitosan sheet was observed to be $16.2 \pm 0.9$. The swelling index of the chitosan sheet was $469.63 \pm 15$. This shows the high efficiency of dressing to absorb wound exudates. The swelling rate depends on the extent of cross linking (crosslinking density), the porous structure of the material, and the forces that act between the solvent (water) and the material (chitosan).

\section{Water vapour transmission rate (WVTR)}

Water-vapour transmission rate is important for wound dressing, because it controls the wound fluid evaporation across the dressing. At the same time, it should not allow the accumulation of exudates in 
the wound area. The rate of water vapour permeability of chitosan sheets were measured at different levels and it shows a transmission rate of $180 \pm 10$ done at $80 \% \mathrm{RH}$ and at $35^{\circ} \mathrm{C}$.

\section{Agar Diffusion Test}

The activity of the released drug from the dressing shows a clear zone of inhibition of $22 \mathrm{~mm}$ controlling the growth of mixed cultures inoculated in the Mueller Hinton agar, whereas full microbial growth was seen around the chitosan sheet without drug, that is, the control. The clear zone of inhibition was maintained for more than 10 days in AMP incorporated chitosan sheet and shown in Figure 1.

\section{FT-IR}

FT-IR spectrum of chitosan sheets show the characteristic peaks of chitosan at 899.20 and $1158 \mathrm{~cm}^{-1}$ corresponding to saccharide structure. Strong absorption peaks at 1640.69 and $1324.02 \mathrm{~cm}^{-1}$ are characteristics of amide I and III peaks, respectively. The peak at $1425.18 \mathrm{~cm}^{-1}$ is assigned to the $\mathrm{CH}_{3}$ symmetrical deformation mode. The peak at $1040.30 \mathrm{~cm}^{-1}$ indicates the $\mathrm{C}-\mathrm{O}$ stretching vibration in chitosan. Another broad peak at $3447 \mathrm{~cm}^{-1}$ is caused by amine $\mathrm{N}-\mathrm{H}$ symmetrical vibration. Peak at 2950 $\mathrm{cm}^{-1}$ is the typical $\mathrm{C}-\mathrm{H}$ stretch vibrations (Figure 2.).

\section{Thermal studies of sheets}

Thermogravimetric analyses (TGA) (Figure 3a.) revealed that the chitosan sheet showed stability upto $200^{\circ} \mathrm{C}$. The second stage of weight loss started at $200^{\circ} \mathrm{C}$ and continued upto $781^{\circ} \mathrm{C}$ (with $31.85 \%$ remaining).

DSC thermogram (Figure 3b.) of chitosan showed an initial broad peak at around $98^{\circ} \mathrm{C}$ which is due to loss of moisture on heating. This was followed by further decomposition of chitosan as a broad exotherm in sheet at around $279^{\circ} \mathrm{C}$.

\section{XRD studies}

The wide angle X-ray diffraction (WAXD) pattern of pure chitosan powder and chitosan sheet in Figure 4. showed the main diffraction peaks around $2 q=20^{\circ}$. But the peak intensity ratio of chitosan sheet was decreased when compared to peak intensity of pure chitosan powder, although the crystalline peaks still remain. This indicated the crystallinity of the chitosan has been decreased.

\section{Rate of wound contraction}

Visual inspection of the wound showed that all the animals had well formed granulation tissues by day 4 . A visual proof of the healing pattern of the wound was photographed on $0,4,8,12$ and 16 days after wound creation and depicted in Figures 5A, 5B, 5C, 5D, 5E \& 5F. 
Wounds of group I rats (Negative control) were reduced to $27.42 \%$ of the original wound area on day 4 of wound creation. The experimental groups ( $\mathrm{G} I \mathrm{I}-\mathrm{G} \mathrm{VI})$ showed significant $(\mathrm{p}<0.05)$ wound reduction $(40 \%$, $36.3 \%, 40 \%, 32 \%$ and $42.25 \%$, respectively) compared to the control animals (G I) on day 4 of wound creation with more prominent reduction in animals treated with AMP incorporated chitosan sheet. The same trend continued after 4,12 and $16^{\text {th }}$ day, indicating wound contraction was significant throughout the healing period. Animals treated with AMP incorporated chitosan showed faster rate of wound contraction $(97.23 \%)$ on day 14 , followed by AMP at higher concentration $(96.71 \%)$ on day 15 , then by AMP at lower concentration (94.0\%) on day 16 , and animals treated only with chitosan showed $92.98 \%$ healing on day 16 (Figure 6.). The period of epithelialization of control and experimental groups is presented in Table 2. In our study, the rate of wound contraction in treated rats was significantly higher. Furthermore, the period of epithelialization was shorter for the treated wounds. These results further support the effectiveness of AMP produced by B.amyloliquefaciens MBL27 for wound healing.

\section{Microbial count}

Swab was taken on the wounded site on $3^{\text {rd }}, 5^{\text {th }}, 7^{\text {th }}, 14^{\text {th }}$ and $21^{\text {st }}$ day taking care that the entire site of the wound was covered, from the day of wound creation and the microbial count was estimated as colony forming units $(\mathrm{CFU} / \mathrm{ml})$. There was a significant $(\mathrm{p}<0.001)$ reduction in bacterial population from $10^{4}$ cells to $10^{1}$ cells on the $3^{\text {rd }}$ and $8^{\text {th }}$ day, respectively for AMP incorporated chitosan sheet. But for animals treated with chitosan sheet the reduction is from $10^{4}$ to $10^{2}$ cells only (Figure 7.). Similarly, significant $(p<0.05)$ reduction in microbial count was noticed for other groups also when compared to control animals. The antimicrobial property of the AMP is responsible for the reduction of the microbial count.

\section{Biochemical analysis}

\section{Protein content}

Figure 8. shows the total protein content in the granulation tissues of control (G I) and experimental wounds $(\mathrm{G} \mathrm{II}-\mathrm{G} \mathrm{VI)}$. The protein content had a statistically significant $(\mathrm{p}<0.05)$ increase in experimental groups ( $\mathrm{G} \mathrm{II}-\mathrm{G} \mathrm{VI}$ ) and was maintained upto day 12 of wound creation indicating the synthesis of other extracellular matrix protein other than collagen in the granulation tissues by the infiltrating cells. Group III showed a significant $(p<0.05)$ increase in protein level in the granulation tissues on $4^{\text {th }}$ day by $43.19 \%$ compared to control animals (G I). Similar trend was observed on $12^{\text {th }}$ day. Group IV showed a significant $(p<0.05)$ increase in protein level in the granulation tissues on $4^{\text {th }}$ day by $59.69 \%$ compared to control animals (G I). Similar trend was observed on $12^{\text {th }}$ day by $62 \%$. Group $V$ showed a significant $(p<0.05)$ increase from $4^{\text {th }}$ day $(30.89 \%)$ to $12^{\text {th }}$ day $(47.58 \%)$, respectively whereas Group VI showed a significant $(p<0.001)$ increase from $4^{\text {th }}$ day $(69.63 \%)$ to $12^{\text {th }}$ day $(77.79 \%)$, respectively compared to controls $(G I)$. The increase in the total protein content indicates active synthesis and deposition of matrix proteins in the granulation tissues. 


\section{Collagen content}

The total collagen content of granulation tissues on various days is presented in Figure 9. A significant $(p<0.05)$ increase in collagen content was observed in experimental rats $(G \|-G \mathrm{VI})$ compared to controls (G I), throughout the course of healing, which is an important constituent of extracellular matrix for healing. Group II animals showed a significant $(p<0.05)$ increase in collagen content on day $4,8,12$ and $16^{\text {th }}$ day when compared to controls (G I). Similar observations were found in the cases of G III, G IV, $\mathrm{G} V$ and $\mathrm{G}$ VI animals. A significant $(\mathrm{p}<0.001)$ increase in collagen content from day $4(143.45 \%)$ to 8 (106.09\%), respectively was observed in G VI animals compared to control animals.

Increased fibroblasts proliferation and dense collagen deposition is observed during later stages of healing particularly in the remodelling phase. As a result there is an increase in the total collagen content in all the experimental groups undergoing proper healing.

\section{Hexosamine content}

The results of hexosamine content in granulation tissues of control and experimental wounds have been shown in Figure 10. Hexosamine content was significantly increased in all experimental groups (G II - G $\mathrm{VI})$ compared to controls (G I) with G VI showing increased content than all other groups. G III animals showed a significant $(p<0.05)$ increase in hexosamine content when compared to controls $(G I)$ and it was $48.75 \%, 32.26 \%, 13.27 \%$ and $58.4 \%$ on $4,8,12$ and $16^{\text {th }}$ day, respectively. A significant $(p<0.05)$ increase in hexosamine content was found in G IV animals when compared to controls (G I) and it was $90.82 \%, 70.92 \%, 31.41 \%$ and $78.73 \%$ on $4,8,12$ and $16^{\text {th }}$ day, respectively. A significant $(p<0.001)$ increase was observed in $\mathrm{G} \mathrm{VI}$ animals also when compared to controls ( $\mathrm{G} \mathrm{I})$. In addition, among the groups, G III and G VI had significantly higher values $(p<0.05)$ than the other experimental groups, followed by $\mathrm{G} V$ and $\mathrm{G} \mathrm{VI}$ and then by G III and G IV.

\section{Uronic acid content}

Table 3 presents the uronic acid levels in the granulation tissues of the control and experimental wounds. The synthesis of ground substance uronic acid was increased upto day 12 post-wounding in the treated groups ( $\mathrm{GI}-\mathrm{G} \mathrm{VI})$, thereafter the levels decreased.

The increase in hexosamine and uronic acid contents in the granulation tissues could be attributed to the formation of glycosaminoglycans (one of the ECM proteins) for which these two ingredients forms the backbone. They are the first components of ECM to be synthesized during wound healing and form the template for collagen and elastin deposition. There was a significant $(p<0.05)$ increase in the uronic acid levels in all experimental groups ( $\mathrm{G} \mathrm{II}-\mathrm{G} \mathrm{VI}$ ) compared to controls $(\mathrm{G} I)$, with $\mathrm{G} \mathrm{VI}$ showing higher values compared to other treatment groups. Among the groups, G IV and G VI showed a statistically significant $(p<0.001)$ increase on 8,12 and $16^{\text {th }}$ day.

\section{Histopathology}


In G I (Negative control) epidermal layer is still not formed well. But infiltration was reduced and macrophages were also observed below the epidermal layer. In G II (Positive control) histological features of normal skin were clearly observed with beginning of remodelling of skin. A well formed epidermis was noticed along with hair follicles emerging from the epidermal layer. In G III (AMP at lower concentration) well formed epithelia were seen with dermal layer containing mature fibroblasts and collagen deposition. In G IV (AMP at higher concentration) epithelial proliferation with well formed collagen bundles was observed. Hair follicles were also found. In G V (Chitosan sheet) wounded area was covered with epithelium. Collagen deposition was also observed. In G VI (AMP incorporated Chitosan sheet) complete epithelialization was seen. Mature fibroblastic cells were seen in the dermal region with collagen deposition. Healing was complete with surface being covered by epithelial cells (Figure 11.).

Masson's Trichrome staining was used to examined the extent of collagen deposition in the wounds. Figure 12. shows the histological sections of both control ( $\mathrm{GI}$ ) and experimental groups (G II - G VI) taken on $16^{\text {th }}$ day. Masson's trichrome staining stains collagen and yields a blue colour. The pattern of staining intensity corresponds to the relative quantity of collagen-fiber deposit, which reflects the process of synthesis and degradation and remodeling as well as the timing of the lesion. Experimental groups (G $I I-G \mathrm{VI}$ ) showed well formed epithelial layer with intense collagen deposition when compared to controls (G I). Well formed hair follicles along with sebaceous gland were also observed. Experimental groups (G II - $\mathrm{G} \mathrm{VI}$ ) also depict the compact and well aligned arrangement of collagen layers except for controls (G I) where only very slight collagen was observed. The bundles of collagen were also thicker in AMP incorporated chitosan sheet $(\mathrm{G} \mathrm{VI})$ treated group than controls $(\mathrm{G} \mathrm{I})$.

\section{Discussion}

This study describes the beneficial effects of AMP produced by B.amyloliquefaciens MBL27 when used alone and in combination with chitosan, on rat dermal wound for healing of the wound. The positive influence of supernatants from Lactobacillus cultures on wound healing and angiogenic properties [23] has prompted us to investigate the AMP produced by B.amyloliquefaciens MBL27 which had very good antimicrobial effects on wound pathogens. Topically applied drugs were effective in quick wound contraction because of larger availability at the wound site. In this study, the wound contraction rate was significantly higher in treated rats. Furthermore, the period of epithelialization was shorter for the treated

wounds. These results further support the effectiveness of AMP produced by B.amyloliquefaciens MBL27 for wound healing.

Hexosamine and uronic acid are matrix molecules which act as ground substances for the synthesis of extracellular matrix. The levels of hexosamine and uronic acid was increased during the early stages of wound healing, following which normal levels are restored [24]. The early increase in hexosamine and uronic acid showed that the fibroblasts actively synthesize the base substratum on which collagen is placed. By providing more fluid uronic acid in the wound attracts fibroblasts and stimulates collagen synthesis. This facilitates greater cell mobility, early remodelling, and assists the wounds to heal faster without scar formation. 
Both the control wounds and wounds treated with AMP showed good influx of inflammatory cells, initially which consisted first mostly of PMNs. Later the inflammatory cell count decreased in the experimental group particularly in AMP incorporated chitosan treated group. The well formed epithelial layer in the regenerated wounds in AMP treated group may be related to the chemotactic nature of collagen, which attracts and helps in the proliferation of cells that provided a moist environment and enhanced epithelialization. The surrounding extracellular matrix as well as the connective tissue deposited in the wound gel plays an important role in the contractile process. These matrices provide the anchoring points and connecting cables to which contractile cells [25] bind and attempt to reduce the wound volume through an active contraction process [26].

The role of collagen in dermal wound repair is an important one. It participates directly or indirectly, in every phase of wound healing and its metabolism during the course of process eventually contribute to the quality of wound repair [27]. The biochemical aspects that accompany wound healing are governed by the metabolism of the cells infiltrating the wound [28]. The rate of wound repair is influenced positively by presence on non-damaged connective tissue cells and factors, which control these movement and proliferation.

\section{Conclusion}

This study showed that AMP produced by B.amyloliquefaciens MBL27 can promote the formation of the collagen, thus accelerate the wound healing. The use of AMP produced by B.amyloliquefaciens MBL27 seemed to have a certain promoting effect on wound healing according to the collagen content and arrangement. To the best of our knowledge, this was the first detailed study on the wound healing efficacy and antimicrobial potential of the bioactive antimicrobial protein from bacterial source done using rat animal model studies taking the various levels of biochemical parameters such as total protein, total collagen, hexosamine and uronic acid prevailing during the period of wound healing, as markers of good wound healing.

The results of the study indicate that AMP produced by B.amyloliquefaciens MBL27 may be a potential candidate for dermal wound healing in view of its antimicrobial properties and also its positive influence on different phases of the healing process.

\section{Declarations}

\section{ACKNOWLEDGEMENT}

The author wishes to thank Dr. Hilda, Microbiology Laboratory CLRI, for the support in carrying out this animal experiment.

Code Availability N/A 
Author contribution: Dr. K. Vijayalakshmi - methodology, conceptualization, practical investigation, formal analysis, writing - original draft

Dr. G. Suseela Rajakumar - editing and review of the draft, supervision, validation

\section{Funding}

This work was supported by Council of Scientific and Industrial Research (CSIR) (Grant number A/6(276)/2008/EMR-I dated 15.03.2008).

\section{Data availability (N/A)}

Ethics Approval Institutional Animal Ethics Committee (IAEC) constituted by Central Leather Research Institute, Chennai, INDIA approved all the protocols of animal experiments of this study (IAEC Reg.No. 06/002/08).

\section{Consent to Participate (N/A)}

Consent for Publication Consent is given

Competing Interests The authors declare no competing interests.

\section{References}

1. Artue, M., Hermes, B., Steclings, U. M., Grutzkau, A., \& Henz, B. M. (1999). Mast cells and their mediators in cutaneous wound healing-active participants or innocent by staders. Experimental Dermatology, 8, 1-16. DOI: 10.1111/j.1600-0625.1999.tb00342.x

2. Noli, C., \& Miolo, A. (2001). The mast cell in wound healing. Veterinary Dermatology, 2, 303-313. DOI: 10.1046/j.0959-4493.2001.00272.x

3. Forest, R. D. (1982). Early history of wound treatment. Journal of the Royal Society of Medicine, 75, 198-205.

4. Minagawa, T., Okamura, Y., Shigemasa, Y., Minami, S., \& Okamoto, Y. (2007). Effects of molecular weight and deacetylation degree of chitin/chitosan on wound healing. Carbohydrate Polymers, 67, 640-644. DOI:10.1016/j.carbpol.2006.07.007

5. Deters, A., Petereit, F., Schmidgall, J., \& Hensel, A. (2008). N-Acetyl-D-glucosamine oligosaccharides induce mucin secretion from colonic tissue and induce differentiation of human keratinocytes. Journal of Pharmacy and Pharmacology, 60, 1-8. DOl:10.1016/j.carbpol.2006.07.007

6. Kojima, K., Okamoto, Y., Miyatake, K., Kitamura, Y., \& Minami, S. (1998). Collagen typing of granulation tissue induced by chitin and chitosan. Carbohydrate Polymers, 37, 109-113.

DOI: 10.1016/s0144-8617(98)00055-1

7. William, G. M., \& Herbert, J. Q. (1985). Method of achieving hemostasis inhibiting fibroplasia and promoting tissue regeneration in a tissue wound. US patent No. 4532134. 
8. Bevins, C. L., \& Zasloff, M. (1990). Peptides from frog skin. Annual Review of Biochemistry, 59, 395414. https://doi.org/10.1146/annurev.bi.59.070190.002143

9. Clarke, B. T. (1997). The natural history of amphibian skin secretions, their normal functioning and potential medical applications. Biological Reviews of Cambridge Philosophical Society, 72, 365-379. DOI: $10.1017 / \mathrm{s} 0006323197005045$

10. Li, J., Xu, X., Xu, C., Zhou, W., Zhang, K., Yu, H., Zhang, Y., Zheng, Y., Rees, H. H., Lai, R., \& Yang, D. (2007). Anti-infection peptidomics of amphibian skin. Molecular and Cellular Proteomics, 6, 882-894. DOI:10.1074/mcp.M600334-MCP200

11. Conlon, J. M., Kolodziejek, J., \& Nowotny, N. (2004). Antimicrobial peptides from ranid frogs: taxonomic and phylogenetic markers and a potential source of new therapeutic agents. Biochimica et Biophysica Acta, 1696, 1-14. DOI:10.1016/j.bbapap.2003.09.004

12. Li-Li, Jin., Qiang, Li., Shu-Sen, Song., Kai Feng, Dian-Bao, Zhang., Qiu-Yu, Wang., \& Yu-Hua. (2009). Characterization of antimicrobial peptides isolated from the skin of the Chinese frog, Rana dybowskii. Comparative Biochemistry and Physiology Part B: Biochemistry and Molecular Biology, 154, 174-178. DOI: 10.1016/j.cbpb.2009.05.015

13. Desboisa, A. P., Gemmell, C. G, \& Cootea, P. J. (2010). In vivo efficacy of the antimicrobial peptide ranalexin in combination with the endopeptidase lysostaphin against wound and systemic meticillinresistant Staphylococcus aureus (MRSA) infections. International Journal of Antimicrobial Agents, 35, 59-565. doi: 10.1016/j.jiantimicag.2010.01.016.

14. Vijayalakshmi, K., \& Suseela Rajakumar, G. (2010). Antimicrobial protein production by Bacillus amyloliquefaciens MBL27: An application of statistical optimization technique. African Journal of Microbiology Research, 4, 2388-2396.

15. Viney, C., \& Harison, D. (2001). Chitosan-preparation and properties. Indian Drugs, 39, 191-194.

16. Morgen, P. W., Binnington, A. G., Miller, C. W., Smith, D. A., Valliant, A., \& Presscott, J. F. (1994). The effect of occlusive and semiocclusive dressings on the healing of acute full-thickness skin wounds on the forelimbs of dog. Veterinary Surgery, 23, 494-502. doi: 10.1111/j.1532-950x.1994.tb00511.x.

17. Loke, W. K., Lau, S. K., Yong, L. L., Khor, E., \& Sum, C. K. (2000). Wound dressing with sustained antimicrobial capability. Journal of Biomedical Materials Research, 53, 8-17. DOI: 10.1002/(sici)10974636(2000)53:1<8::aid-jbm2>3.0.co;2-3

18. Porat, S., Roussa, M., \& Shosan, S. (1956) Improvement of the gliding functions of flexor tendons by topically applied enriched collagen solution. Journal of Bone and Joint Surgery, 62, 315-323. doi: 10.1302/0301-620X.62B2.6245095.

19. Lowry, O. H., Rosebrough, N. J., Farr, A. L., \& Randall, R. J. (1951). Protein measurement with the Folin phenol reagent. Journal of Biological Chemistry, 193, 265-275.

20. Woessner, J. F., \& Arch. (1961). The determination of hydroxyproline in tissue and protein samples containing small portions of this imino acid. Archives of Biochemstry and Biophysics, 93, 440-447. doi: 10.1016/0003-9861(61)90291-0. 
21. Elson, L. A., \& Morgan, W. T. G. (1933). A colorimetric method for the determination of glucosamine and chondrosamine. The Journal of Biochemistry, 27, 1824-1828. doi: 10.1042/bj0271824.

22. Schiller, S., Slover, G. A., \& Dorfman, A. (1961). A method for the separation of acid mucopolysaccharides: its application to the isolation of heparin from the skin of rats. Journal of Biological Chemistry, 236, 983-988.

23. Halper, J., Leshin, L. S., Lewis, S. J., \& Li Wi. (2003). Wound healing and angiogenic properties of supernatants from Lactobacillus cultures. Experimental Biology and Medicine, 228, 1329-1337. doi: $10.1177 / 153537020322801111$.

24. Nithya, M., Suguna, L., \& Rose, C. (2003). The effect of nerve growth factor on the early responses during the process of wound healing. Biochimica Et Biophysica Acta, 1620, 25-31. doi: 10.1016/s0304-4165(02)00501-9.

25. Majno, G., Gabbiani, G, Hirschel, B. J., Ryan, G. B., \& Statkov, P. R. (1971). Contraction of granulation tissue in vitro: similarity to smooth muscle. Science, $173,548-550$.

DOI: 10.1126/science.173.3996.548

26. Gabbiani, G., \& Majno, G. (1972). Dupuytren's contracture: fibroblast contraction? An ultrastructural study. The American Journal of Pathology, 66, 131-146.

27. McPherson, J. M., \& Piez, K. A. (1988). The molecular and cellular biology of wound repair. Plenum, New York: P. 471-496.

28. Falcone, P., \& Caldwell, M. (1990). Wound metabolism. Clinics in Plastic Surgery, 17, 443-456.

\section{Tables}

Table 1 Physical properties of chitosan sheet

\begin{tabular}{|ll|}
\hline Thickness $(\mathrm{mm})$ & $40-45$ \\
\hline Moisture content $(\mathrm{MC} \%)$ & $16.2 \pm 0.9$ \\
\hline WVTR $\left(\mathrm{g} / \mathrm{m}^{2} /\right.$ day $)$ & $180 \pm 10$ \\
\hline Swelling index $(\mathrm{SI})$ & $469.63 \pm 15$ \\
\hline Tensile strength $\left(\mathrm{N} / \mathrm{mm}^{2}\right)$ & $89.67 \pm 10.04$ \\
\hline$\%$ Elongation & $6.42 \pm 0.12$ \\
\hline
\end{tabular}

Table 2 Period of epithelialization in control and experimental rats 


\begin{tabular}{|ll|}
\hline Groups & Days \\
\hline G I (negative control) & $21.34 \pm 1.23$ \\
\hline G II (positive control) & $15.2 \pm 1$ \\
\hline G III (AMP at lower concentration) & $16.3 \pm 0.45$ \\
\hline G IV (AMP at higher concentration) & $15.1 \pm 0.34$ \\
\hline G V (Chitosan film) & $16.04 \pm 0.56$ \\
\hline G VI (AMP incorporated chitosan film) & $14.01 \pm 0.54$ \\
\hline
\end{tabular}

Table 3 Uronic acid content ( $\mathrm{mg} / 100 \mathrm{mg}$ dry tissue) in granulation tissue of control and experimental groups (Mean \pm S.E)

\begin{tabular}{|c|c|c|c|c|}
\hline Groups & $4^{\text {th }}$ day & $8^{\text {th }}$ day & $12^{\text {th }}$ day & $16^{\text {th }}$ Day \\
\hline G I & $0.47 \pm 2.49$ & $1.58 \pm 0.97$ & $1.23 \pm 0.33$ & $1.20 \pm 1.2$ \\
\hline G II & $2.11 \pm 1.2^{\star}$ & $4.23 \pm 0.81$ * & $4.68 \pm 0.74 *$ & $3.95 \pm 1.05^{\star}$ \\
\hline G III & $2.82 \pm 1.33^{*}$ & $3.88 \pm 0.66^{*}$ & $4.05 \pm 1.0^{*}$ & $2.87 \pm 0.66^{*}$ \\
\hline G IV & $4.11 \pm 1.05^{\star}$ & $5.95 \pm 2.36$ ** & $5.23 \pm 1.35^{\star \star}$ & $4.12 \pm 0.33^{\star \star *}$ \\
\hline G V & $3.4 \pm 0.66^{*}$ & $4.86 \pm 0.78^{*}$ & $4.23 \pm 0.43^{\star}$ & $4.03 \pm 0.81$ * \\
\hline G VI & $5.4 \pm 0.84$ ** & $5.99 \pm 0.83^{\star *}$ & $5.06 \pm 1.05^{\star \star}$ & $4.87 \pm 1.33^{*}$ \\
\hline
\end{tabular}

* $p<0.05 ;{ }^{* *} p<0.001$

Figures 


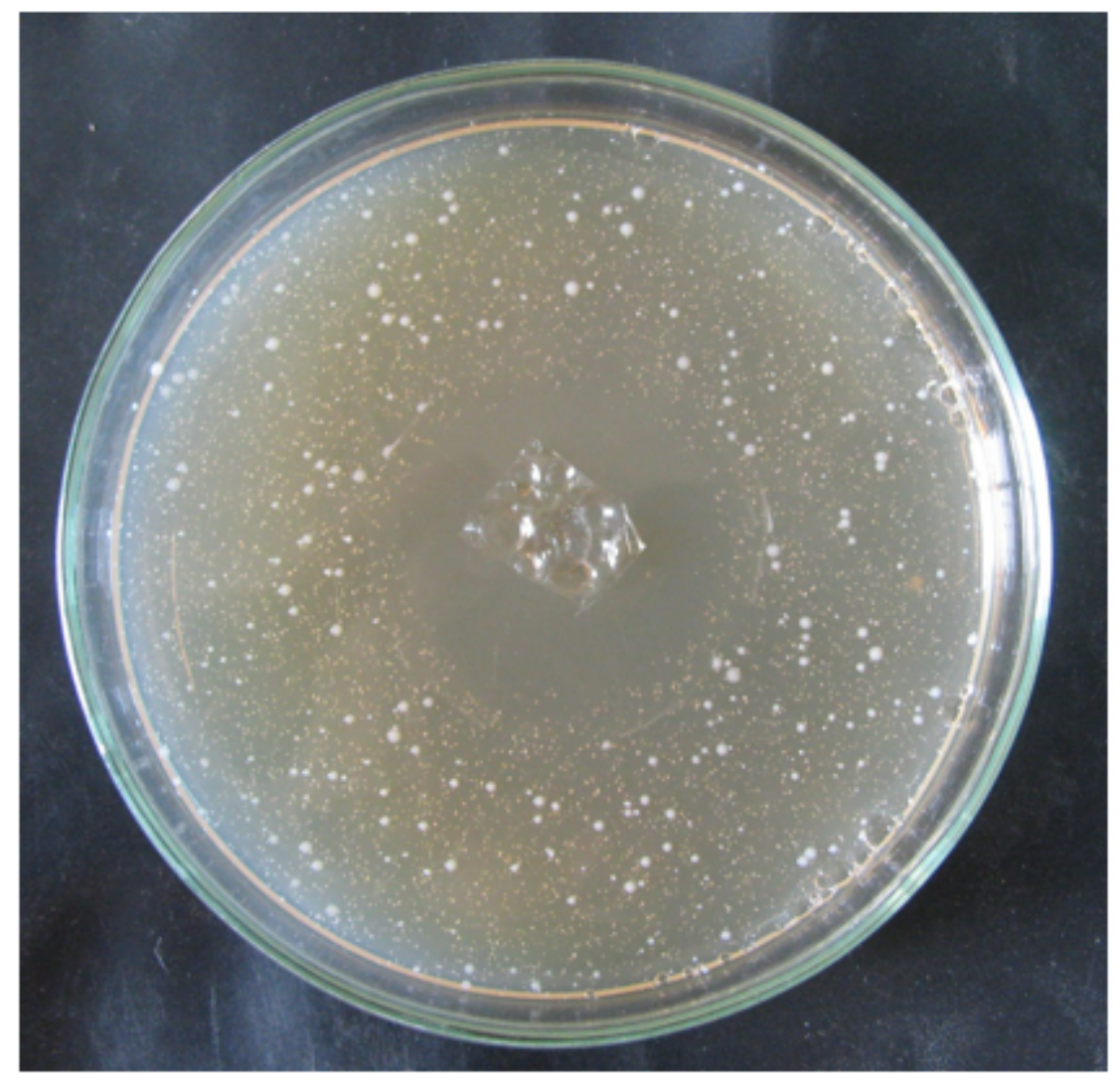

Figure 1

Plate showing zone of clearance for AMP incorporated chitosan sheet against mixed culture

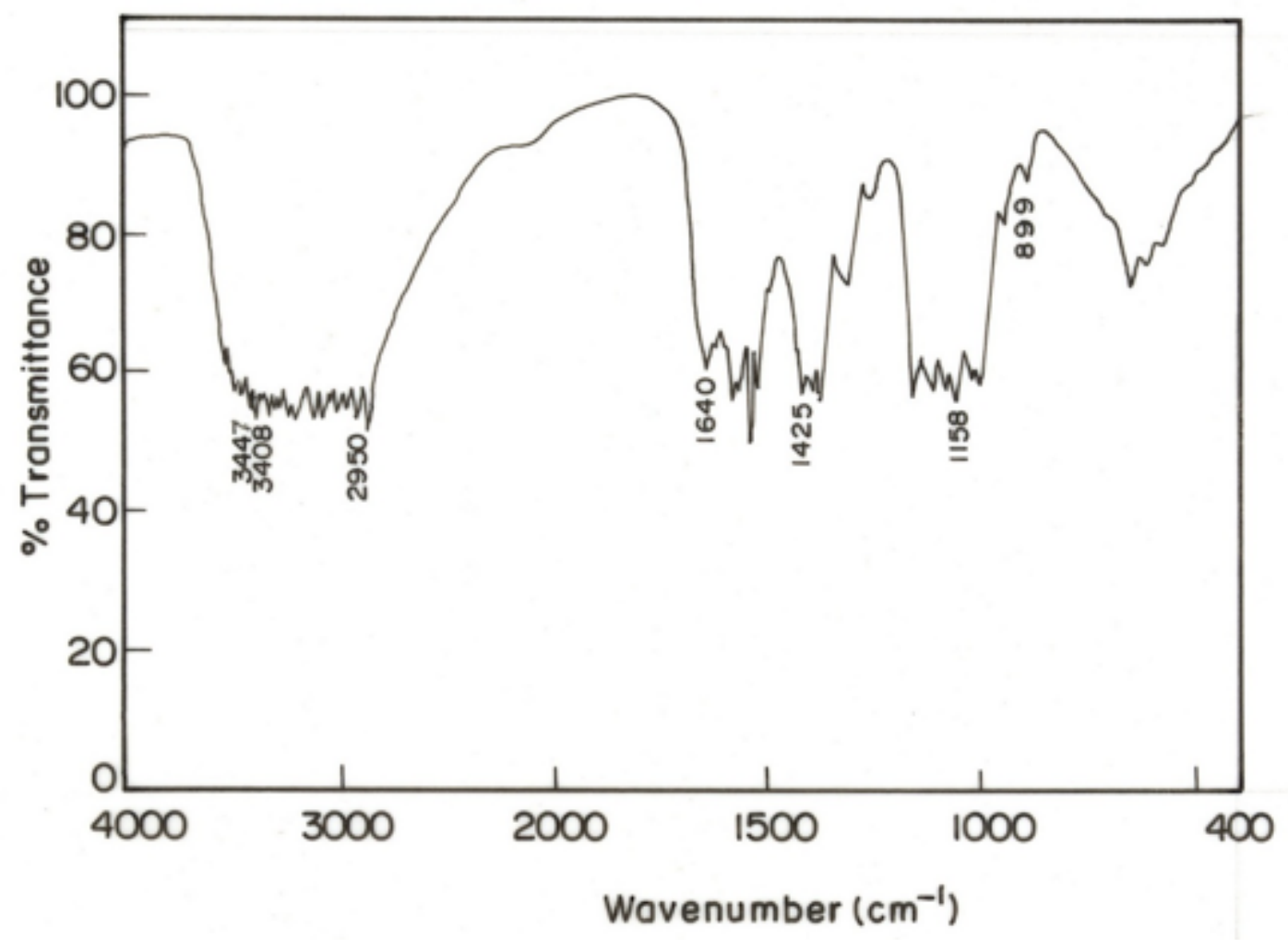

Figure 2 
FT-IR spectrum of chitosan sheet

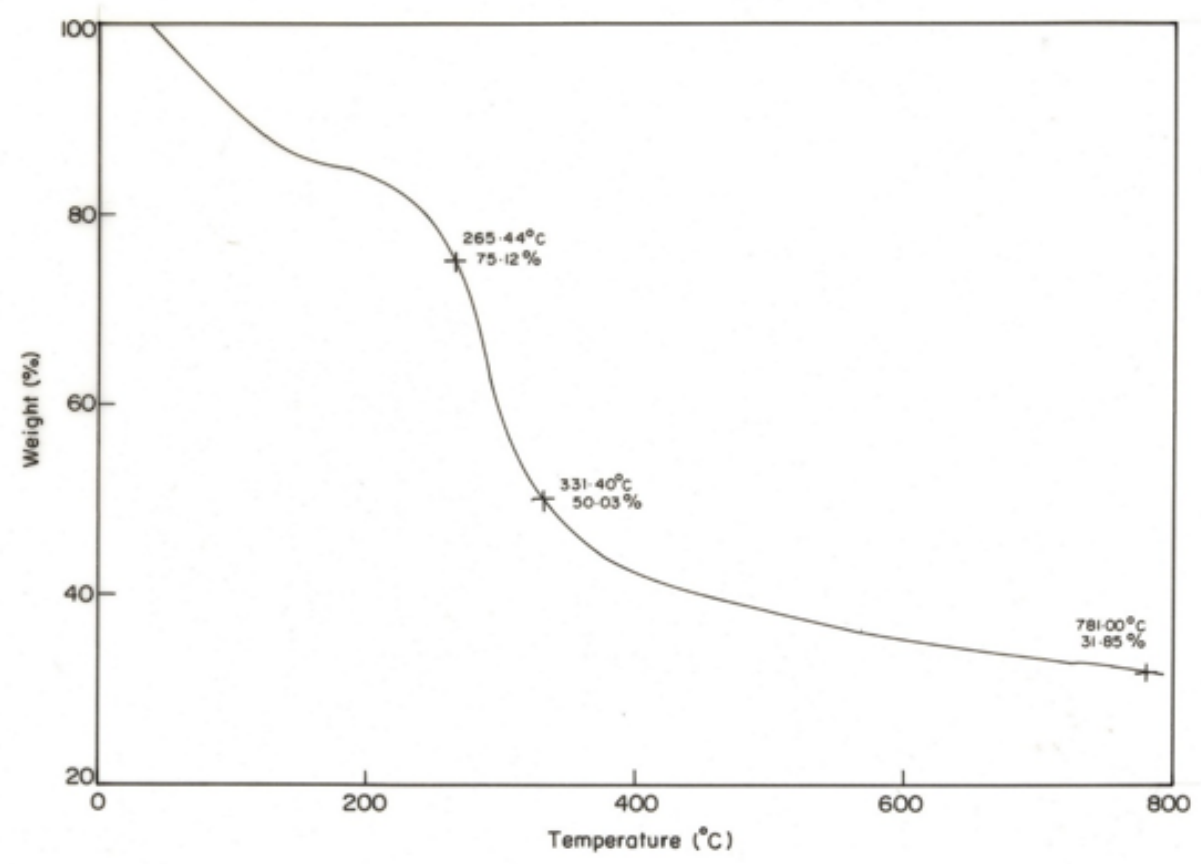

a

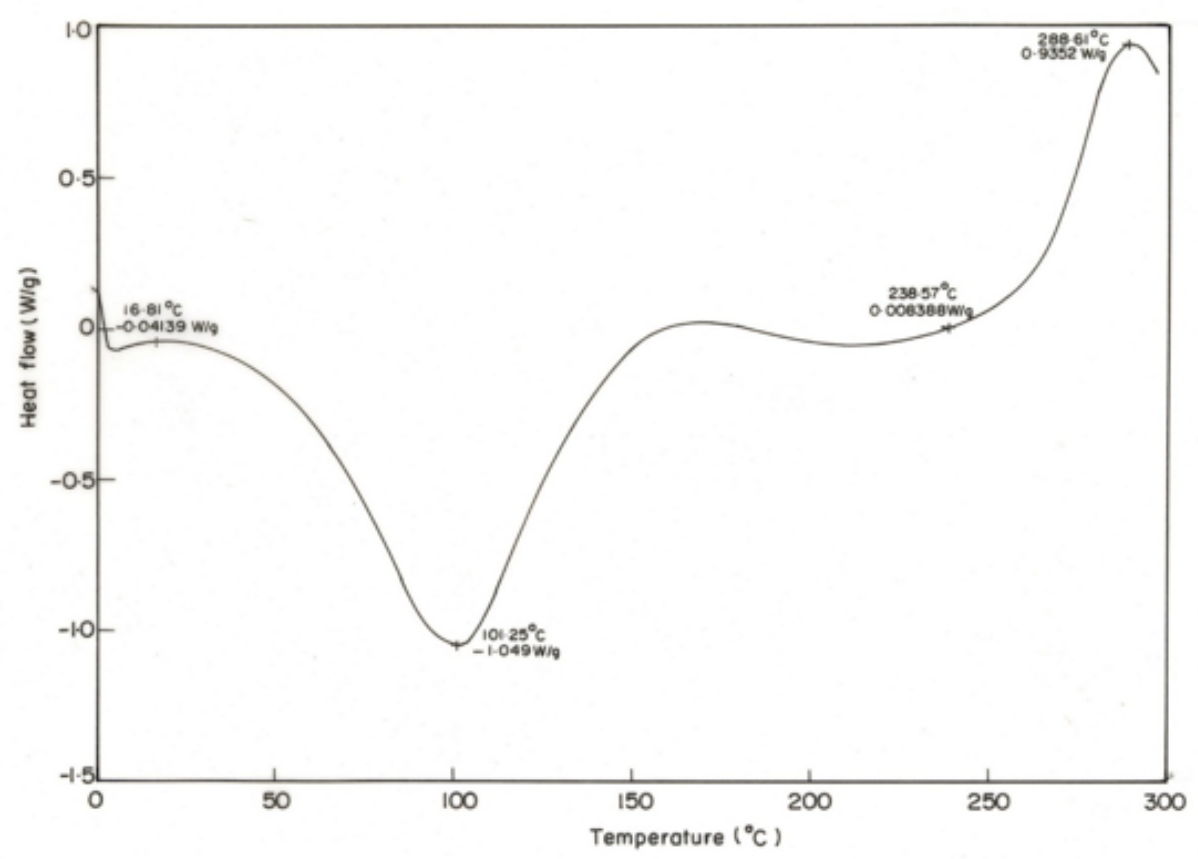

b

Figure 3

a. TGA thermogram of chitosan sheet b. DSC thermogram of chitosan sheet 


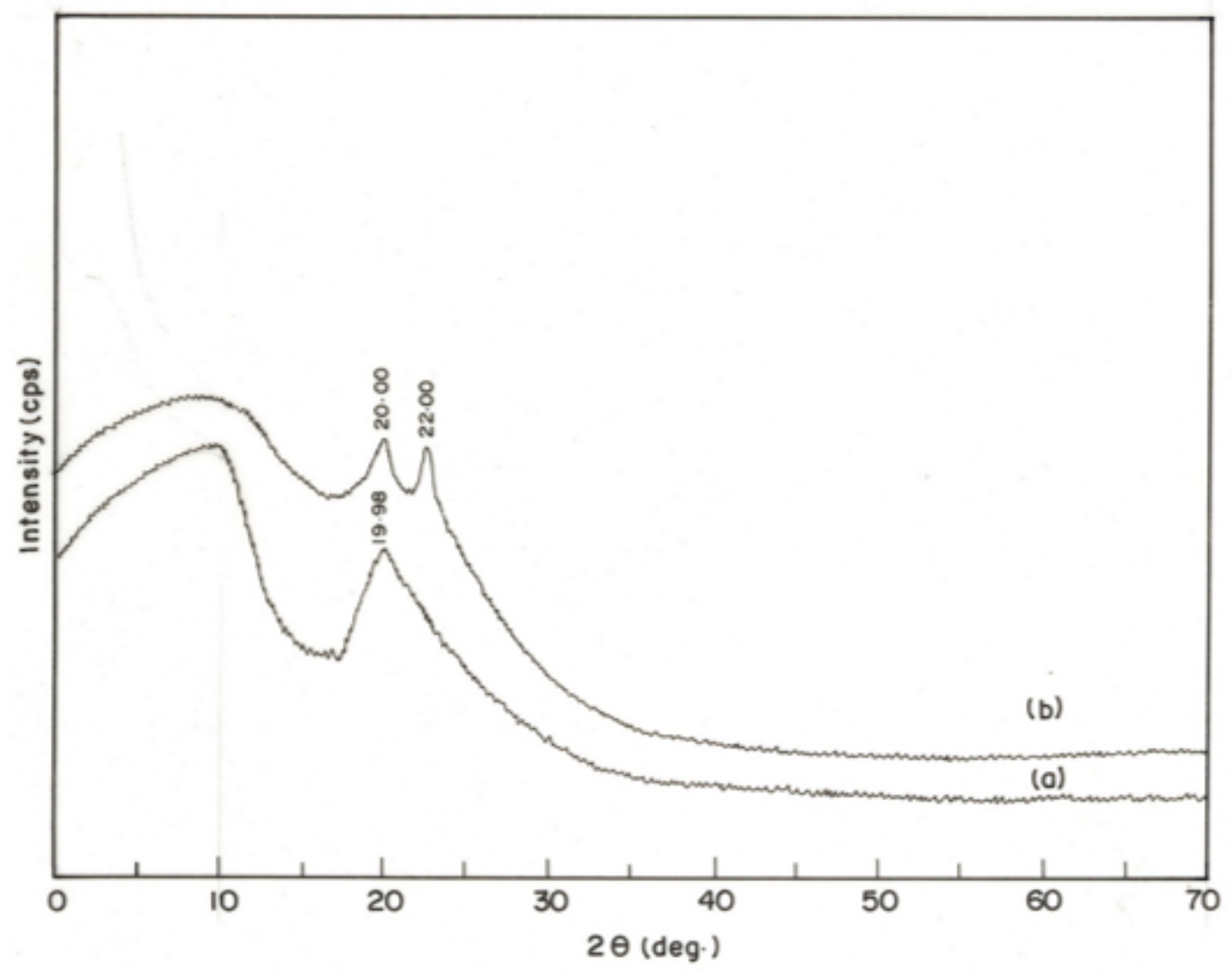

a) Chitosan powder b) Chitosan sheet

Figure 4

XRD diffractogram of chitosan sheet a) Chitosan powder b) Chitosan sheet 

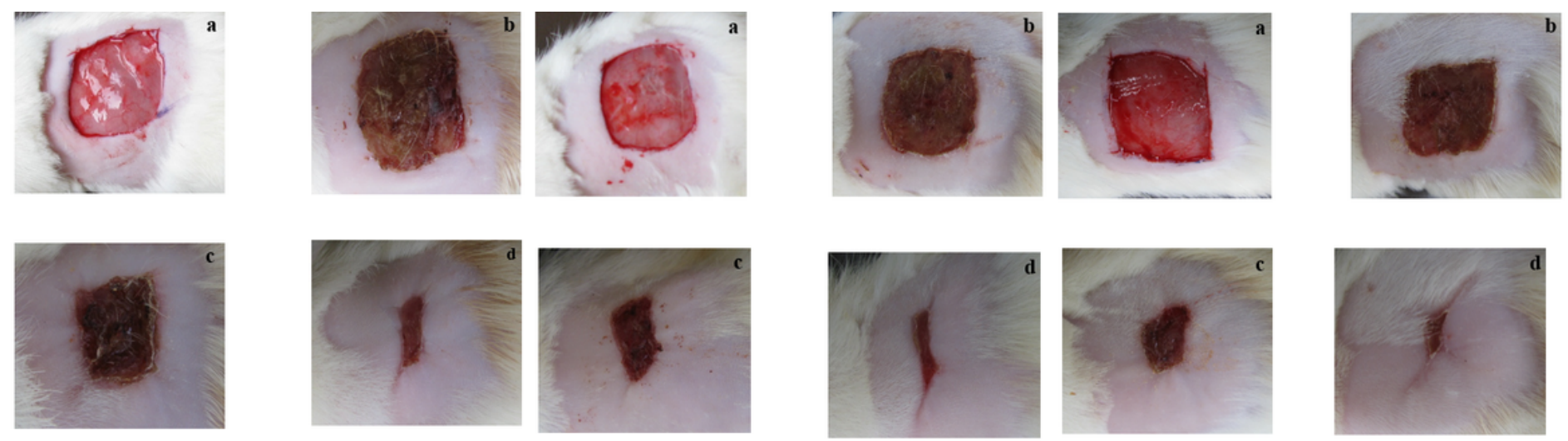

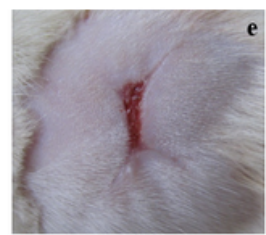

A
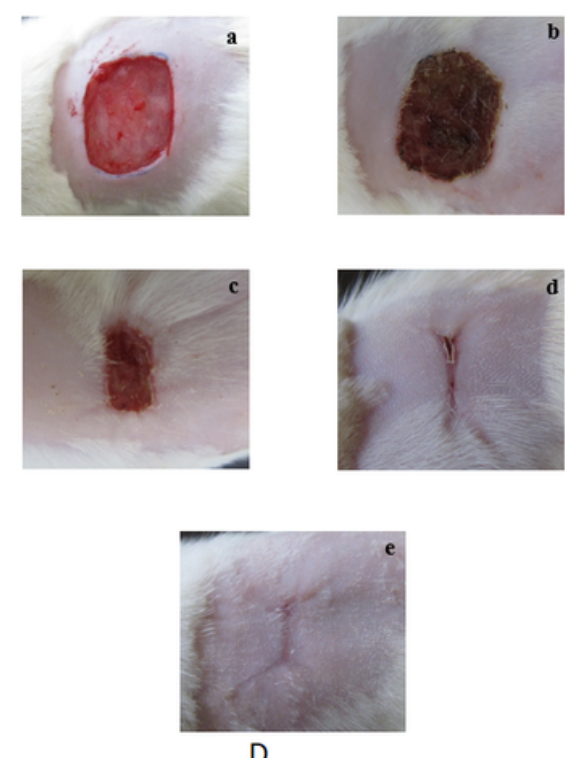

D

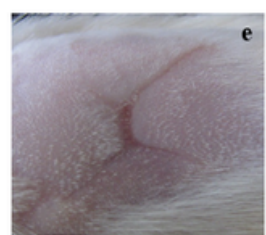

B
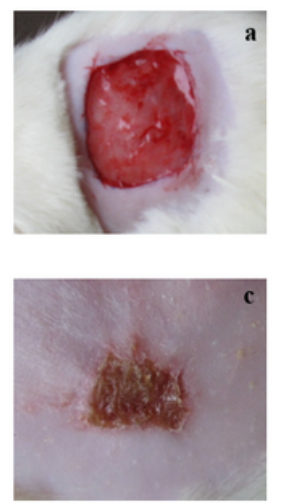
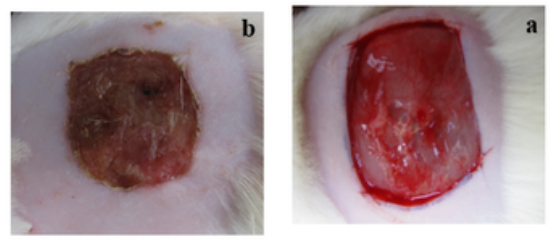

C
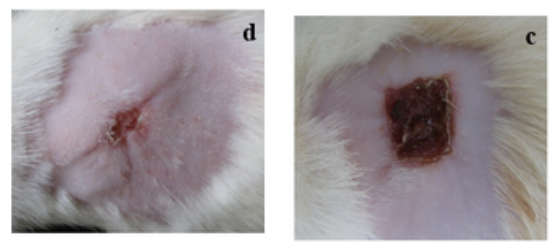
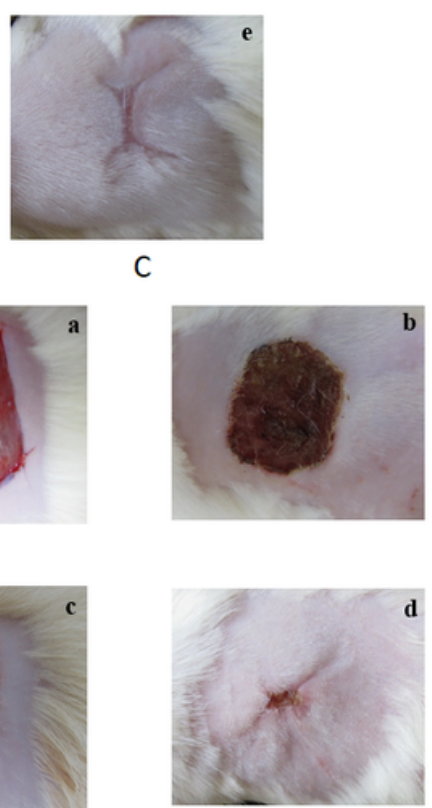

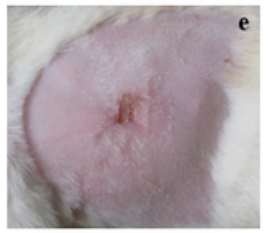

$\mathrm{E}$

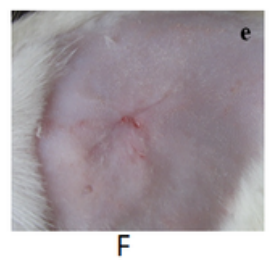

\section{Figure 5}

A Photographs showing the wound healing pattern of control (G I) wounds taken on a) 0th day b) 4th day c) 8th day d) 12th day and e) 16th day after wound creation B Photographs showing the wound healing pattern of Cipladine (povidone-iodine) treated (G II) wounds taken on a) 0th day b) 4th day c) 8th day d) 10th day and e) 15th day after wound creation $C$ Photographs showing the wound healing pattern of wounds treated with AMP ( $1 \mathrm{mg} / \mathrm{cm} 2$ wound area) (G III) taken on a) 0th day b) 4th day c) 8th day d) 12th day and e) 16th day after wound creation $D$ Photographs showing the wound healing pattern of wounds treated with AMP ( $2 \mathrm{mg} / \mathrm{cm} 2$ wound area) (G IV) taken on a) 0th day b) 4th day c) 8th day d) 12th day and e) 15th day after wound creation E Photographs showing the wound healing pattern of wounds treated with chitosan sheet (G V) taken on a) 0th day b) 4th day c) 8th day d) 12th day and e) 
16th day after wound creation $F$ Photographs showing the wound healing pattern of wounds treated with AMP incorporated chitosan sheet ( $\mathrm{G} \mathrm{VI}$ ) taken on a) 0th day b) 4th day c) 8th day d) 12th day and e) 14th day after wound creation

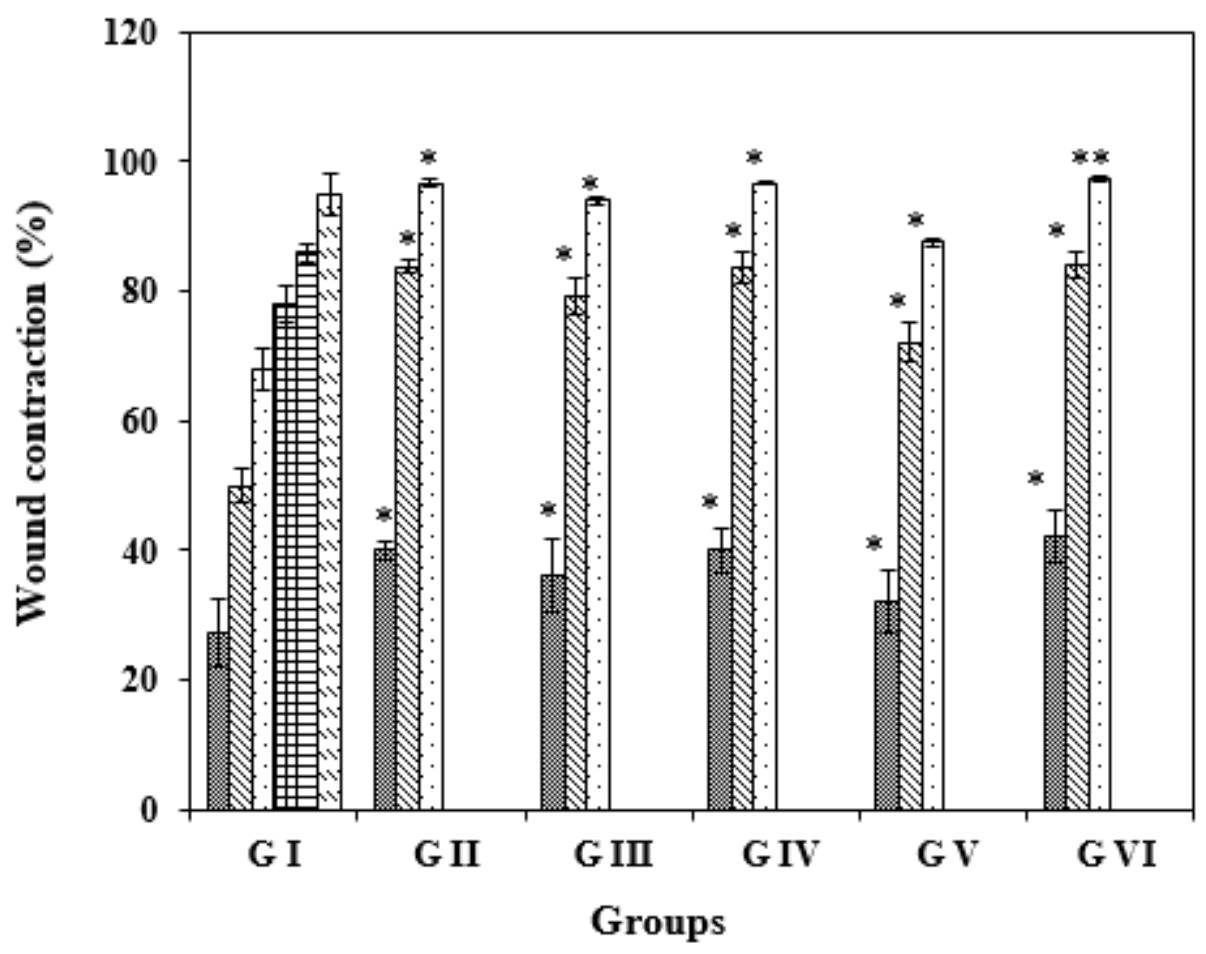

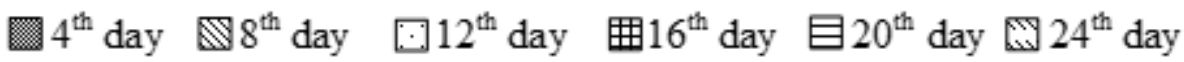

$* \mathrm{p}<0.05 ; * * \mathrm{p}<0.001$

Figure 6

Percentage of wound contraction of control (G I) and experimental groups ( $\mathrm{G} \mathrm{II}-\mathrm{G} \mathrm{VI}$ ) during different days of wound healing 


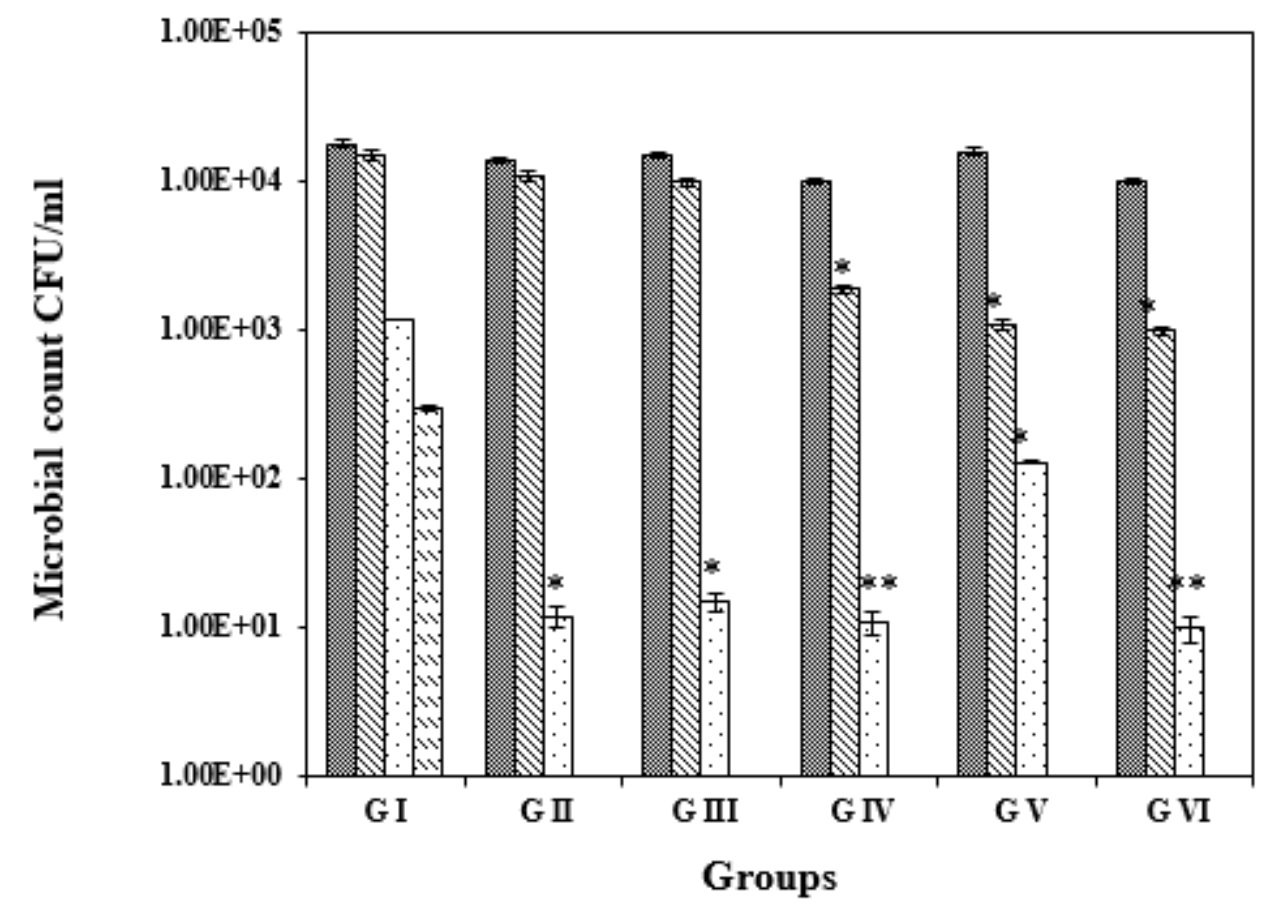

D $4^{\text {th }}$ day $\mathbb{Q} 8^{\text {th }}$ day $\because 12^{\text {th }}$ day $⿴ 16^{\text {th }}$ day

$* \mathrm{p}<0.05 ; * \mathrm{p}<0.001$

Figure 7

Microbial population dynamics (CFU/ml) on wound site during different days of wound healing 


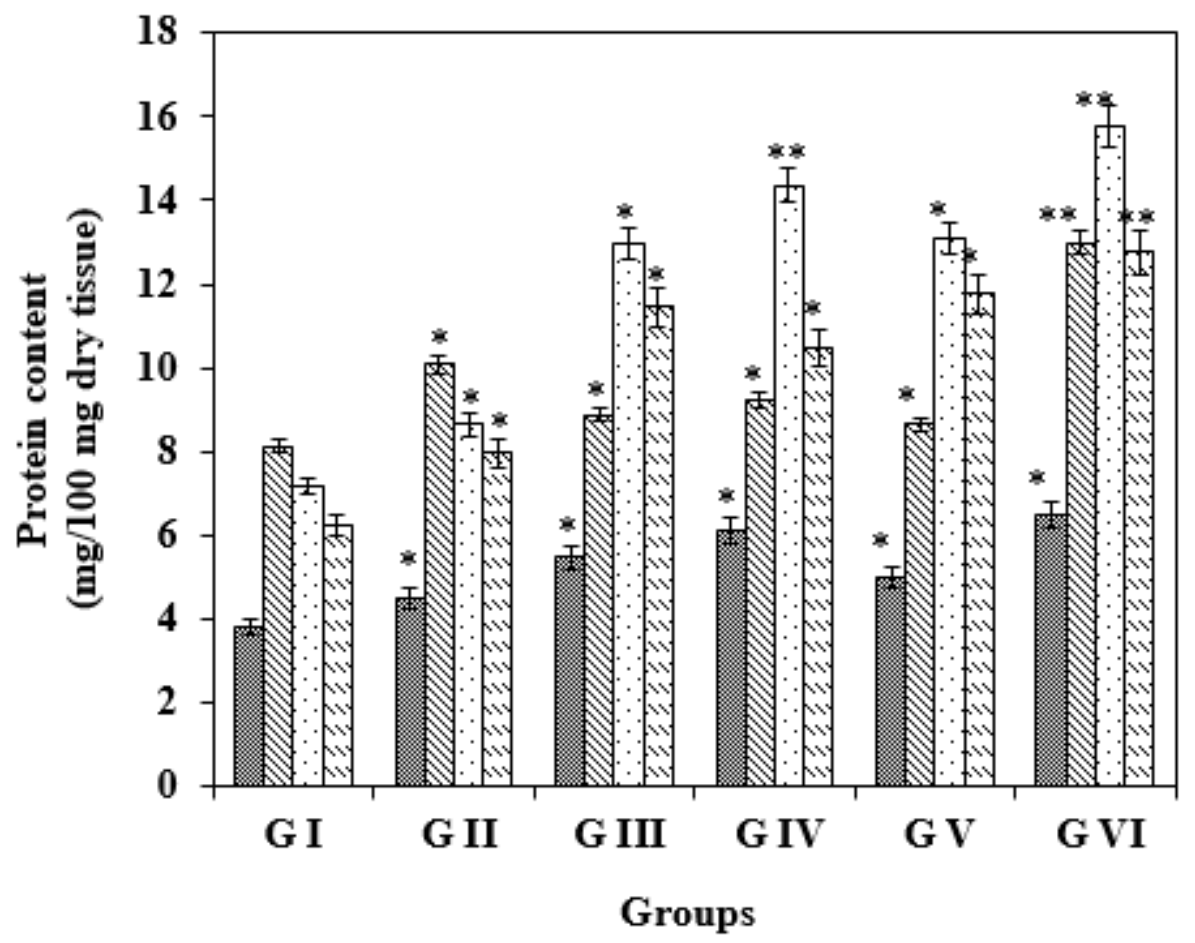

$\square 4^{\text {th }}$ day $\mathbb{8 ^ { \text { th } }}$ day $\square 12^{\text {th }}$ day $\quad \mathbb{1}^{\text {th }}$ day

$* \mathrm{p}<0.05 ; * \mathrm{p}<0.001$

Figure 8

Protein content in granulation tissue during different days of wound healing on various treatment groups 


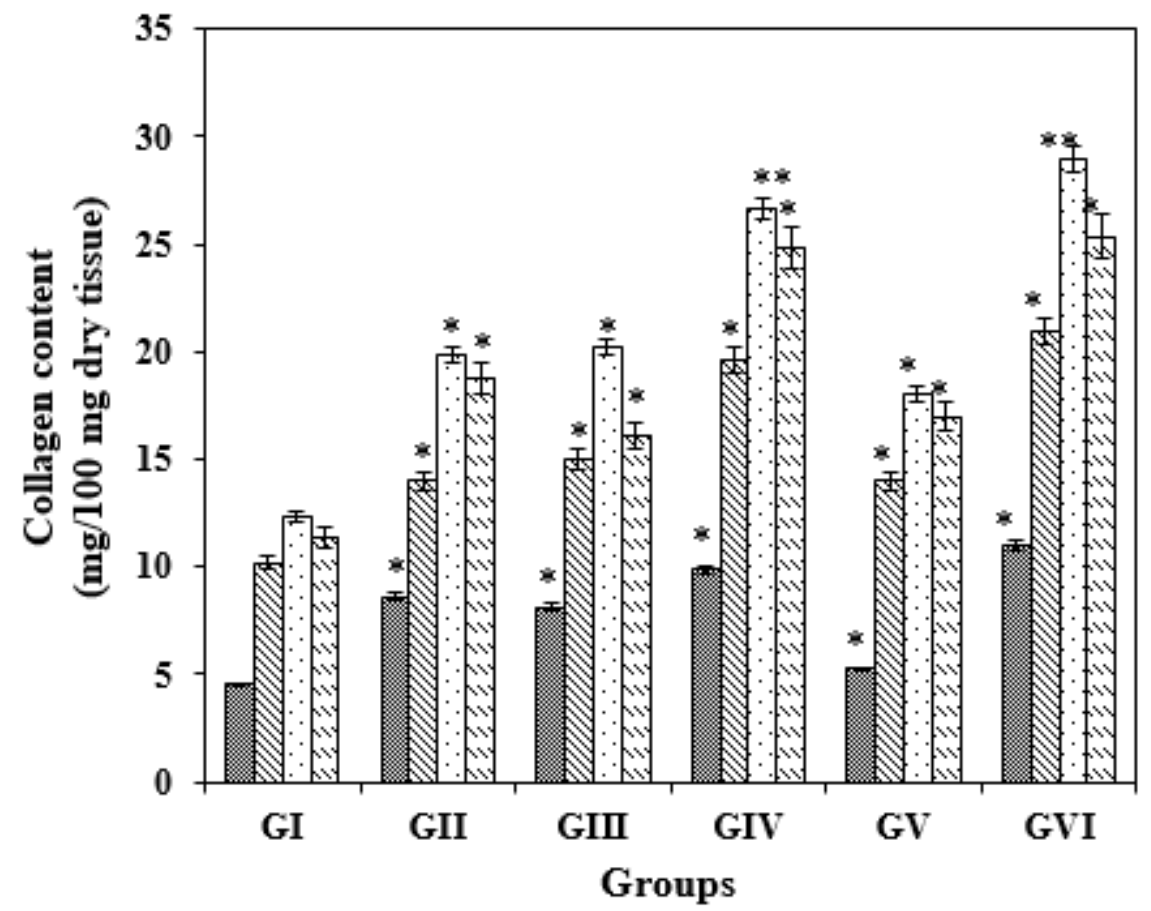

$4^{\text {th }}$ day $\mathbb{Q}^{\text {th }}$ day $\quad \cdot 12^{\text {th }}$ day $\mathbb{1}^{\text {th }}$ day

$* \mathrm{p}<0.05 ; * \mathrm{p}<0.001$

Figure 9

Total collagen content in granulation tissue of control and experimental groups 


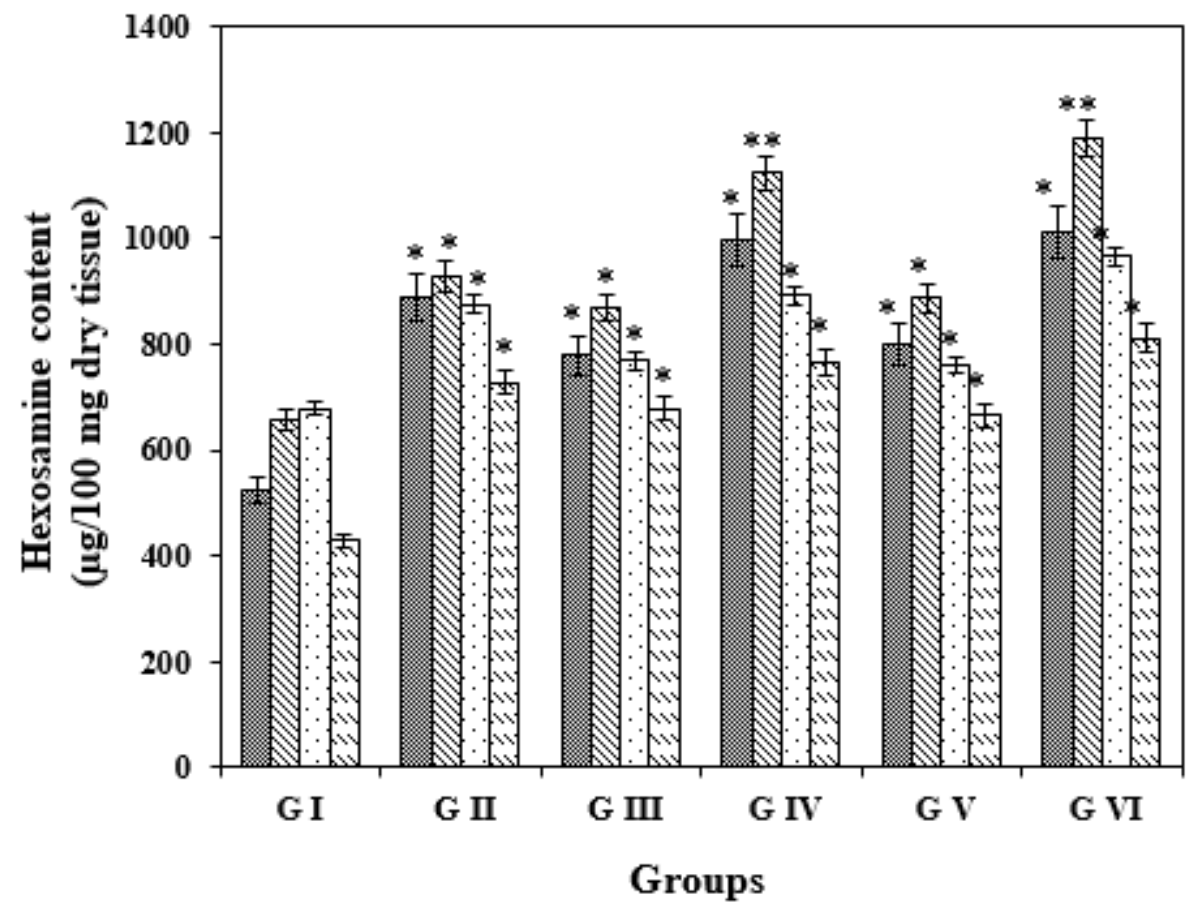

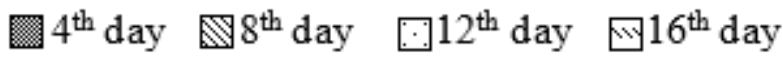

$* \mathrm{p}<0.05 ; * \mathrm{p}<0.001$

Figure 10

Hexosamine content in granulation tissue of control and experimental groups 

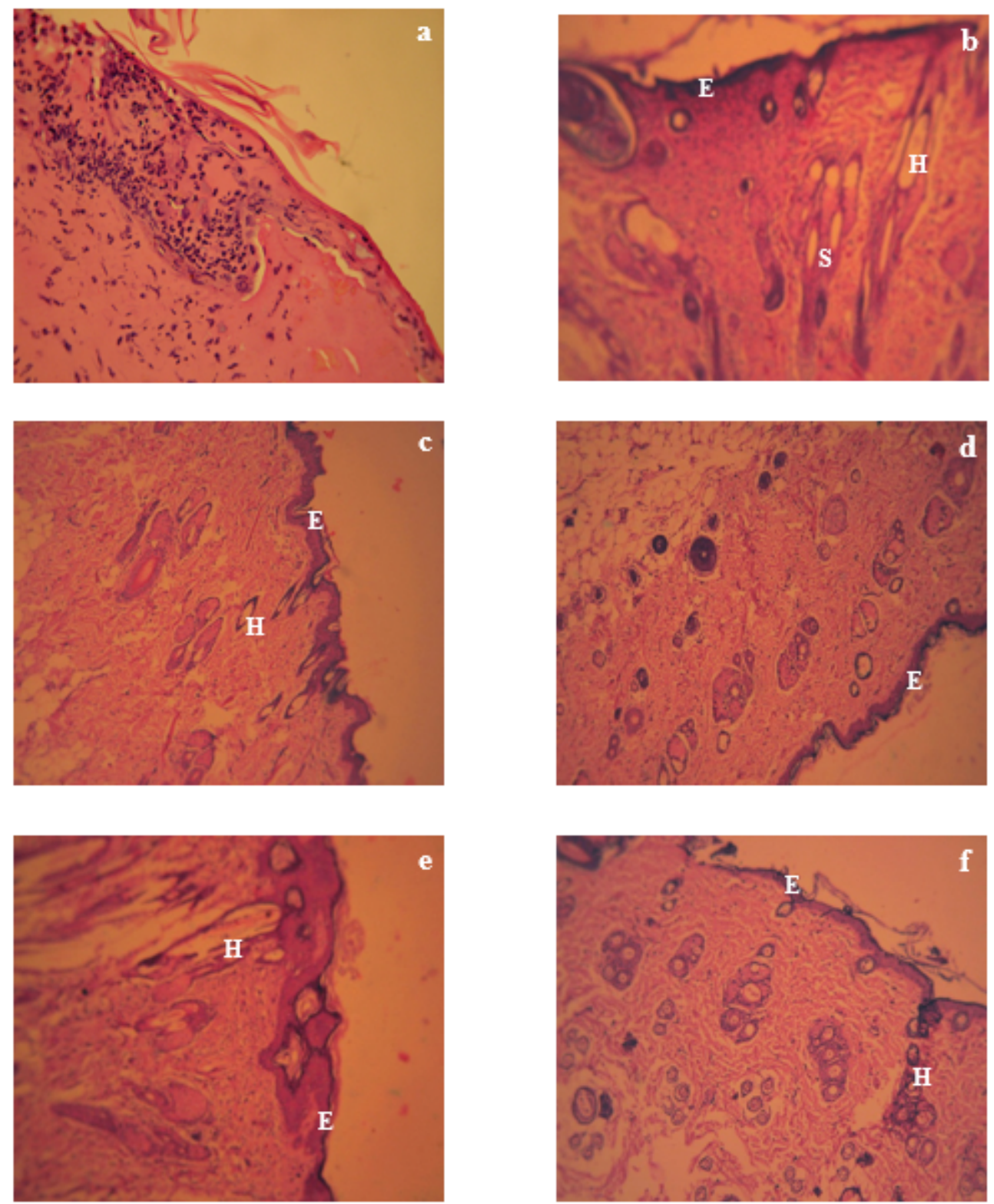

* I-Inflammatory cells, E-Epidermis, H-Hair follicle, S-Sebaceous glands

\section{Figure 11}

Photomicrographs (100x) of healing wound tissue taken on 16th day a) negative control (G I), b) positive control (G II), c) AMP at lower concentration (G III) d) AMP at higher concentration (G IV) e) Chitosan sheet (G V) f) AMP incorporated chitosan sheet (G VI) 

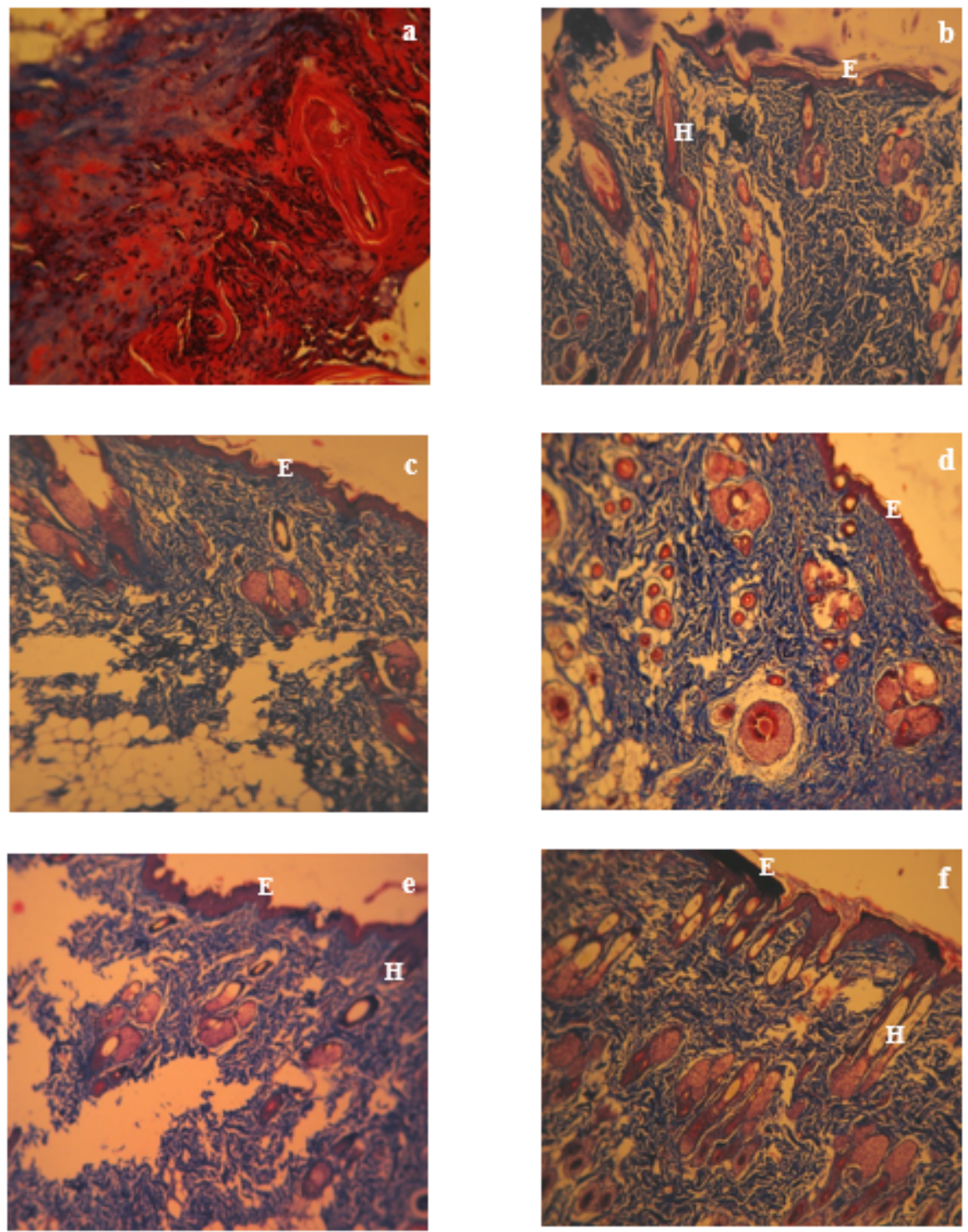

* I-Inflammatory cells, E-Epidermis, H-Hair Follicles

Blue colour denotes collagen deposition on Masson's trichrome staining

\section{Figure 12}

Photomicrographs (100x) of healing wound tissue taken on 16th day a) negative control (G I), b) positive control (G II), c) AMP at lower concentration (G III) d) AMP at higher concentration (G IV) e) Chitosan sheet (G V) f) AMP incorporated chitosan sheet (G VI) 